\title{
Radical changes urged in UK curriculum
}

[LONDON] The British government has responded cautiously to a report on the school science curriculum that suggests that pupils should spend less time memorizing facts and more time pursuing original ideas and developing an awareness of how science works.

The report, published last week by the Nuffield Foundation, is the outcome of a series of nationwide seminars held to review the effectiveness of the school science curriculum. The seminars were held over two years and involved teachers, schools inspectors, educationalists, members of professional science bodies, and the Qualifications and Curriculum Authority, the government body responsible for the school curriculum.

According to the report, pupils should learn how to discriminate between competing scientific claims, how ideas in science change over time, and how to evaluate the strengths and weaknesses of media reports of science. After the age of 14, it suggests, half of the science curriculum time should be spent studying these issues.

Carolyn Swain of the Qualifications and Curriculum Authority says the authority is unlikely to incorporate any radical elements into its review of the school curriculum. This is partly because some of the report's ideas are already part of the curriculum - such as courses in the nature of science, its applications, and science communication - but also to give teachers time to get used to the existing curriculum, which was changed substantially by the previous government.

The overall reaction to the report has been mixed. Most of the recommendations have been endorsed by science bodies, including the Institute of Physics and the Royal Society of Chemistry, which both say they are relaxed at the prospect of a reduction in the factual content of school science.

Colin Osborne, schools and colleges education officer at the society, says there is little in the report that will concern the chemistry community, providing that the proposed new curriculum is not considered a 'soft option' and continues to challenge pupils.

Osborne agrees with the report that the current curriculum does not meet the future needs of most pupils. Similarly, the government's chief scientific adviser, Sir Robert May, says it is "excellent". At the launch of the document, May said that teaching science as a set of facts "left me fairly uninterested in science when I was at high school".

He added: "Many dilemmas in public policy arise because of the belief that science can answer all questions. But the truth is that in many cases we just don't know. Science is not a set of clear answers to well-defined questions."

But employers are less enthusiastic, and fear that, despite assurances, it may lead to a further decline in standards of assessment that are believed to have been caused by the introduction of the national curriculum a decade ago.

Peter Clark, a senior policy adviser at the Confederation of British Industry, says that, merit, the above-average performance of British schoolchildren in international education surveys such as the Third International Mathematics and Science Study, suggests that pupils have a better grasp of science than the report implies.

Swayn says that the report's authors seem to have an outdated view of the present curriculum. "The idea that science is taught [wholly] as a discrete set of facts is possibly a hangover from previous versions of the curriculum," she says, adding that any reduction in the facts presently taught must be debated and discussed considerably before - if at all — it is implemented. For example, she says, lessons on the implications of discoveries such as BSE or cloning require a basic understanding of biology.

But the authors deny that their proposals amount to a lowering of standards, another concern of the Confederation of British Industry. The report says that pupils who want to study a subject in more detail — possibly as a step towards a career in science should be allowed to do so, although Jonathan Osborne, senior lecturer in science although the proposed reforms have some

education at King's College London, and one of the report's co-authors, says that these pupils will always be a minority.

He says that the curriculum should aim to meet the needs of the majority of pupils who will not become professional researchers. "This does not amount to 'dumbing down', says the other co-author, Robin Millar, professor of science education at the University of York.

The curriculum was originally designed as a foundation course for future scientists. But, despite many attempts to make it more relevant to those not intending to pursue careers in science, the authors say that "tension" remains between the aims of promoting scientific literacy and providing the first stage of a training in science.

Some problem areas remain in the curriculum, say the authors, including the fact that pupils find science "uninteresting and alienating", that there is no increase in the number taking science beyond the age of 16 , and that many adults have low levels of scientific literacy despite spending about ten years studying science at school.

The authors do not expect their proposals to be implemented in the short term. They also recognize that teachers will need convincing of the need for further change, and that assessment methods must also change, both of which will take time. "It is better to debate these issues now, when there is time to reflect," says Osborne.

EhsanMasood

\section{'Soft option' for women gets sharp riposte}

[LONDON] Last week's launch of the Nuffield report (see above) on the future of science education was partly overshadowed by a lively exchange between two panelists on how to get more women to take careers in science.

On the day that Peter Mandelson, cabinet minister for science, launched a poster campaign to attract more teenage girls into science (see right), the authors of the report were asked whether they had addressed this issue. Robin Millar, professor of science education at the University of York, said that, although there was no explicit reference to girls and science, the issue was discussed at the seminars.

He then added that a more "humanistic" curriculum, such as that proposed in the report, would appeal more to girls than the present one. This prompted an angry response from Sir Robert May, the government's chief scientific adviser, who described Millar's comments as "absolute rubbish". It is "pernicious nonsense to say that women like soft things. It's the sort of thing we're trying to combat."

May added: "Countries where women do

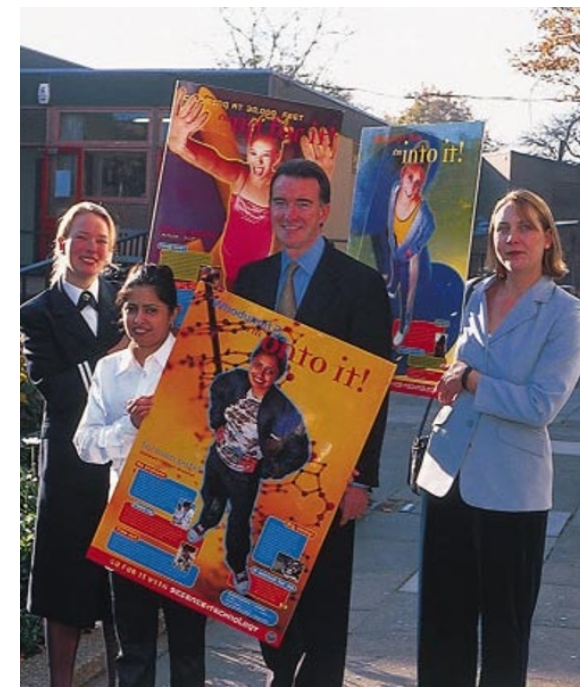

Spreading the message: Mandelson launches a bid for more women in UK science.

well in science offer a good middle-class education, and reliable domestic help." The answer, May concluded, is "tax relief for help at home, and better child care". E.M. 